\title{
Phase-separable catalysis using room temperature ionic liquids and supercritical carbon dioxide
}

\author{
Fuchen Liu, Michael B. Abrams, R. Tom Baker* and William Tumas* \\ Los Alamos Catalysis Initiative, Chemistry Division, MS J514, Los Alamos National Laboratory, Los Alamos, New \\ Mexico 87545, USA. E-mail: weg@lanl.gov; tumas@lanl.gov
}

\author{
Received (in Cambridge, UK) 4th December 2000, Accepted 29th January 2001 \\ First published as an Advance Article on the web 14th February 2001
}

A new phase-separable catalysis concept is demonstrated using supercritical carbon dioxide and the room temperature ionic liquid 1-butyl-3-methylimidazolium hexafluorophosphate for hydrogenation of alkenes and carbon dioxide.

There is a continuing interest in developing new concepts for biphasic or phase-separable catalysis where a homogeneous catalyst is immobilized in one liquid phase and the reactants and/or products reside largely in another liquid phase. ${ }^{1}$ Brennecke and Beckman ${ }^{2}$ have recently reported that the room temperature ionic liquid (IL) 1-butyl-3-methylimidazolium hexafluorophosphate, 1, ([BMIM] $\left.\left[\mathrm{PF}_{6}\right]\right)$, exhibits very interesting phase behavior with supercritical carbon dioxide $\left(\mathrm{scCO}_{2}\right)$, where $\mathrm{CO}_{2}$ can dissolve significantly (up to 0.6 mole fraction) into the lower IL phase, but no polar IL dissolves in the upper $\mathrm{scCO}_{2}$ phase. They further illustrated that organics such as naphthalene could be extracted from the IL phase using $\mathrm{scCO}_{2}$. Kazarian et al. ${ }^{3}$ recently provided corroborating spectroscopic evidence that $\mathrm{CO}_{2}$ dissolves in 1. This intriguing discovery of phase behavior suggested that a reaction system comprised of $\mathrm{scCO}_{2}$ and an ionic liquid might offer particular advantages as a new biphasic catalysis system. Herein, such a $\mathrm{scCO}_{2} / \mathrm{IL}$ biphasic system is demonstrated, where a homogeneous transition metal catalyst is immobilized in an IL phase and products can be isolated from a distinct $\mathrm{scCO}_{2}$ phase. ${ }^{4}$

Room temperature ionic liquids 5 and supercritical carbon dioxide $^{6}$ have both been extensively studied as alternative solvents for a wide range of homogeneously catalyzed reactions including hydrogenation, hydroformylation, selective oxidation and carbon-carbon bond formation. We chose to examine the $\mathrm{scCO}_{2} / \mathrm{IL}$ system through investigations of the hydrogenation of dec-1-ene and cyclohexene using Wilkinson's catalyst $\mathrm{RhCl}\left(\mathrm{PPh}_{3}\right)_{3}, 2$, which is insoluble in $\mathrm{scCO}_{2}$ but soluble in water-stable [BMIM] $\left[\mathrm{PF}_{6}\right], \mathbf{1}$.

All reactions were run in custom-designed, high pressure stainless steel view cells with a sapphire window using magnetic stirring at $50{ }^{\circ} \mathrm{C}$, as described previously. ${ }^{7 \dagger}$ The hydrogenation of dec-1-ene proceeded in $98 \%$ conversion to $n$ decane in $1 \mathrm{~h}$ at $48 \mathrm{bar}_{2}$ and a total pressure of 207 bar, which implies a time-averaged reaction turnover frequency (TOF) of $410 \mathrm{~h}^{-1}$. The reaction mixture was biphasic throughout the reaction with a colorless carbon dioxide phase above a yellow ionic liquid phase. Hydrogenation of cyclohexene proceeded more slowly under identical conditions with $82 \%$ conversion being observed after $2 \mathrm{~h}$ reaction at $50{ }^{\circ} \mathrm{C}$ (time-averaged TOF

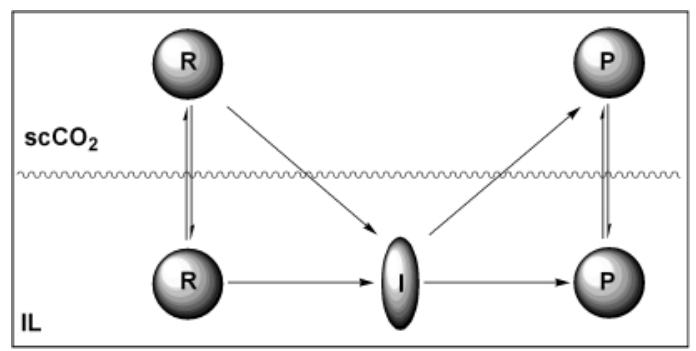

Scheme 1 Pictorial illustration of a $\mathrm{scCO}_{2} / \mathrm{IL}$ biphasic system $\mathbf{R}=$ reactant, $\mathbf{P}=$ product, $\mathbf{I}=$ polar intermediate $($ e.g. carbamate $\mathbf{4})$.
$=220 \mathrm{~h}^{-1}$ ) and $96 \%$ conversion measured after $3 \mathrm{~h}$. Product recovery and catalyst recycling were demonstrated for dec1-ene using a variable volume reaction vessel to transfer the upper $\mathrm{scCO}_{2}$ phase to a separate receiver under high pressure after reaction. ${ }^{8}$ The reaction vessel was then recharged with dec-1-ene, hydrogen and carbon dioxide and allowed to react for $1 \mathrm{~h}$. This process was repeated up to four times and the reaction proceeded to $c a$. $98 \%$ conversion each time, thereby demonstrating efficient catalyst recycling through immobilization of the rhodium catalyst in the ionic liquid.

Since many organic compounds are not miscible with imidazolium-based ionic liquids, many of the reported catalytic reactions in ILs can be considered to be organic/IL biphasic systems. Product separation has been demonstrated in a number of cases. ${ }^{9}$ In order to benchmark the reactivity of the $\mathrm{scCO}_{2} / \mathrm{IL}$ system with organic/IL systems, we also examined the above hydrogenation reactions using $n$-hexane in place of carbon dioxide, under otherwise identical conditions. $\$$ The reaction of dec-1-ene to form $n$-decane proceeded to $99 \%$ conversion after $1 \mathrm{~h}$ at $50{ }^{\circ} \mathrm{C}$ in $n$-hexane/[BMIM] $\left[\mathrm{PF}_{6}\right]$. Conversions of cyclohexene to cyclohexane were similar to those measured in the $\mathrm{scCO}_{2} /[\mathrm{BMIM}]\left[\mathrm{PF}_{6}\right]$ experiments: $88 \%$ after $2 \mathrm{~h}, 98 \%$ after $3 \mathrm{~h}$ at $50{ }^{\circ} \mathrm{C}$. These results suggest that there is no reactivity advantage for $\mathrm{CO}_{2}$ over $n$-hexane for simple hydrogenation reactions.

In order to capitalize on advantages arising from the polar nature of the ionic liquid phase, we sought to examine reactions that proceed through polar intermediates which would be soluble in the IL phase and not in $\mathrm{scCO}_{2}$ (Scheme 1). We studied the hydrogenation of carbon dioxide in the presence of dialkylamines to produce $N, N$-dialkylformamides. Noyori et al. ${ }^{10}$ and Baiker et al. ${ }^{11}$ have reported elegant studies on the catalytic hydrogenation of $\mathrm{CO}_{2}$ to formamides in $\mathrm{scCO}_{2}$ using scCO ${ }_{2}$-soluble $\mathrm{RuCl}_{2}\left(\mathrm{PMe}_{3}\right)_{4}$ and $\mathrm{scCO}_{2}$-insoluble $\mathrm{RuCl}_{2}$ (dppe) $)_{2}\left(\right.$ dppe $\left.=\mathrm{Ph}_{2} \mathrm{PCH}_{2} \mathrm{CH}_{2} \mathrm{PPh}_{2}\right), 3$, respectively. These reactions involve ionic carbamate intermediates, since dialkylamines react with $\mathrm{CO}_{2}$ reversibly to form dialkylammonium dialkylcarbamates, 4 [eqns (3), (4)]. ${ }^{12}$

$$
\begin{aligned}
& \mathrm{CO}_{2}+\mathrm{H}_{2} \stackrel{\text { [cat] }}{\rightleftharpoons} \mathrm{HCO}_{2} \mathrm{H} \\
& \mathrm{HCO}_{2} \mathrm{H}+\mathrm{R}_{3} \mathrm{~N} \rightleftharpoons\left[\mathrm{HNR}_{3}\right]^{+}\left[\mathrm{HCO}_{2}\right]^{-} \\
& \mathrm{HNR}_{2}+\mathrm{CO}_{2} \rightleftharpoons \mathrm{R}_{2} \mathrm{NCO}_{2} \mathrm{H} \\
& \mathrm{R}_{2} \mathrm{NCO}_{2} \mathrm{H}+\mathrm{NHR}_{2} \rightleftharpoons\left[\mathrm{NH}_{2} \mathrm{R}_{2}\right]^{+}\left[\mathrm{O}_{2} \mathrm{CNR}_{2}\right]^{-} \\
& 4 \\
& {\left[\mathrm{NH}_{2} \mathrm{R}_{2}\right]^{+}\left[\mathrm{O}_{2} \mathrm{CNR}_{2}\right]^{-}+2 \mathrm{HCO}_{2} \mathrm{H} \rightarrow} \\
& 2 \mathrm{HCON}(\mathrm{R})_{2}+2 \mathrm{H}_{2} \mathrm{O}+\mathrm{CO}_{2}
\end{aligned}
$$

Noyori et al. reported that salt $4 \mathbf{a}\left(\mathrm{R}=\mathrm{CH}_{3}\right)$ separated from the $\mathrm{scCO}_{2}$ phase right from the start of the reaction starting with dimethylamine and rates using $\mathbf{4 a}$ were similar to those using dimethylamine. Very high rates for selective $N, N$-dimethylformamide (DMF) formation were reported using either liquid $\mathbf{4 a},{ }^{10}$ or dimethylamine. ${ }^{10,11}$ Significantly Noyori et al. found that activity and selectivity (i.e. formic acid vs. 
Table 1 Production of formamides from amines and $\mathrm{CO}_{2}$ in different solvent systems

\begin{tabular}{|c|c|c|c|c|c|c|c|c|}
\hline Amine & Solvent & Catalyst & $T /{ }^{\circ} \mathrm{C}$ & $t / \mathrm{h}$ & Con $(\%)$ & Sel $(\%)$ & $\mathrm{TON}^{a}$ & TOF $\left(\mathrm{h}^{-1}\right)^{b}$ \\
\hline $\mathrm{NH}\left(\mathrm{C}_{2} \mathrm{H}_{5}\right)_{2}{ }^{c}$ & $\mathrm{scCO}_{2}$ & $\mathrm{RuCl}_{2}\left(\mathrm{PMe}_{3}\right)_{4}$ & 100 & 13 & 38 & $46^{d}$ & 820 & 63 \\
\hline $\mathrm{NH}_{2}\left(n-\mathrm{C}_{3} \mathrm{H}_{7}\right)^{c}$ & $\mathrm{scCO}_{2}$ & $\mathrm{RuCl}_{2}\left(\mathrm{PMe}_{3}\right)_{4}$ & 100 & 5 & 18 & $30^{d}$ & 260 & 52 \\
\hline $\mathrm{NH}\left(n-\mathrm{C}_{3} \mathrm{H}_{7}\right)_{2}$ & $\mathrm{scCO}_{2} / \mathrm{IL}$ & $\mathrm{RuCl}_{2}(\mathrm{dppe})_{2}$ & 80 & 5 & 100 & $>99$ & 110 & $>22$ \\
\hline
\end{tabular}

formamide production) decreased rapidly with longer chain amines $\left(\mathrm{R} \neq \mathrm{CH}_{3}\right)$ which lead to solid, $\mathrm{scCO}_{2}$-insoluble carbamate intermediates. ${ }^{10}$

In the $\mathrm{scCO}_{2} / \mathrm{IL}$ system, catalyst $\mathbf{3}$ and carbamate $\mathbf{4}$ are both soluble in the IL phase. Carbamate 4a could be completely converted to DMF after $4 \mathrm{~h}$ at $80{ }^{\circ} \mathrm{C}$ using 55 bar hydrogen under a total pressure of 276 bar.§ While this unoptimized reactivity is significantly less than that reported by Baiker for the liquid carbamate, ${ }^{11}$ \% we found that the reactivity and more importantly the selectivity is higher for amines other than dimethylamine in the $\mathrm{scCO}_{2} / \mathrm{IL}$ biphasic system. Under similar reaction conditions, di- $n$-propylamine $\int[$ led to complete amine conversion and exclusive production of the corresponding $N, N$ di- $n$-propylformamide after only $5 \mathrm{~h}$ at $80{ }^{\circ} \mathrm{C}$. The activity and selectivity are higher than those reported ${ }^{10}$ for less bulky diethylamine and $n$-propylamine in neat $\mathrm{scCO}_{2}$ (Table 1). The increased selectivity in the $\mathrm{scCO}_{2} / \mathrm{IL}$ biphasic system likely arises from the increased solubility of the solid dialkylcarbamate intermediates in the IL phase or through rate enhancement of amidation of formic acid derived from $\mathrm{CO}_{2}$ hydrogenation [eqn (5)].

The highly polar formamide products appear to be very soluble in the ionic liquid phase, $\mathbf{1}$. Preliminary experiments reveal that they do not partition strongly into the $\mathrm{scCO}_{2}$ phase after only one reaction cycle. Quantitative data on the partitioning of organic compounds between ionic liquids and either organic solvents or $\mathrm{scCO}_{2}$ are just starting to appear in the literature. ${ }^{13,14} \mathrm{We}$ have demonstrated extraction of DMF from IL 1 in a separate experiment. After stirring $30 \mathrm{~mL} \mathrm{scCO}{ }_{2}\left(P_{\text {tot }}\right.$ $=276$ bar) over a solution of $1.0 \mathrm{~mL}$ ionic liquid 1 and $1.0 \mathrm{~mL}$ DMF for $1 \mathrm{~h}$ at $80{ }^{\circ} \mathrm{C}$, the upper $\mathrm{CO}_{2}$ phase was transferred under high pressure to another vessel. Subsequent pressure letdown led to $151 \mathrm{mg}$ of isolated DMF (16\% recovery). We have been able to demonstrate effective product recovery for $N, N$-di$n$-propylformamide after several reaction/recovery cycles. The recovery yield in the first cycle was poor (less than $5 \%$ ), however, the yield in the second cycle improved significantly to $61 \%$. $N, N$-di- $n$-propylformamide can be almost quantitatively recovered in the third and fourth cycle, suggesting the IL phase becomes saturated with the product in the first two cycles. ${ }^{15}$

In conclusion, we demonstrate one of the first examples ${ }^{4}$ of catalysis in a biphasic system incorporating supercritical carbon dioxide and ionic liquids and more importantly the first example involving $\mathrm{CO}_{2}$ reaction chemistry. High selectivity, catalyst recycling and product recovery were observed for hydrogenation of $\mathrm{CO}_{2}$ in the presence of dialkylamines, demonstrating the potential advantages arising from dissolving polar reaction intermediates in the IL phase. We are in the process of investigating other reactions, particular those involving polar intermediates, as well as quantifying the partitioning of reactants (including gases), products and catalyst between the two phases.

We gratefully acknowledge support of this research by the U.S. Department of Energy through a Laboratory Directed Research and Development (LDRD) grant at Los Alamos National Laboratory.

\section{Notes and references}

$\dagger$ Typical experimental procedure for olefin hydrogenation: $20 \mathrm{mg}$ (21 $u \mathrm{~mol}$ ) of 2 were added to $10.5 \mathrm{mmol}$ of olefin ( 500 equiv. relative to catalyst 2) and $1 \mathrm{~mL}$ of ionic liquid $\mathbf{1}$ in the reaction cell which was then pressurized with hydrogen (48 bar) and $\mathrm{CO}_{2}$ to a total pressure of 207 bar. All the experiments were conducted at $50{ }^{\circ} \mathrm{C}$ using $n$-nonane as an internal standard.

\$While magnetic stirring may not be optimal for these reactions, our preliminary experimental conditions allow for a semi-quantitative comparison.

§ Typical experimental procedure for $\mathrm{CO}_{2}$ hydrogenation: $0.5 \mathrm{~mL}(4.3$ mmol) of $4 \mathbf{a}$ was charged into a $33 \mathrm{~mL}$ stainless steel reaction cell with a solution of $10 \mathrm{mg}(10 \mathrm{umol})$ of $\mathbf{3} \mathrm{in} 1 \mathrm{~mL}$ of $\mathbf{1}$. The cell was heated to $80{ }^{\circ} \mathrm{C}$ after being filled with 55 bar $\mathrm{H}_{2}$, then it was pressurized to a total pressure of 276 bar with $\mathrm{CO}_{2}$. The start of the reaction was defined as the time of $\mathrm{CO}_{2}$ gas introduction. The yield and identification of formamide were performed by GC, GC-MS and ${ }^{1} \mathrm{H}$ NMR. ${ }^{10}$

II $0.15 \mathrm{~mL}(1.1 \mathrm{mmol})$ of di- $n$-propylamine and $1 \mathrm{~mL}$ of 1 were used. Higher concentration of amine (e.g. $7.3 \mathrm{mmol}$ di- $n$-propylamine in $1 \mathrm{~mL}$ of $\mathbf{1}$ ) led to precipitation of a white solid (carbamate).

1 B. Cornils and W. A. Herrmann, in Applied Homogeneous Catalysis with Organometallic Compounds, ed. B. Cornils and W. A. Herrmann, Weinheim: New York, 1996, Chapter 4.1, pp. 1167-1197; An entire issue of Catalysis Today $(1998,42$ (2)) was devoted to biphasic homogeneous catalysis.

2 L. A. Blanchard, D. Hancu, E. J. Beckman and J. F. Brennecke, Nature, 1999, 399, 28

3 S. G. Kazarian, B. J. Briscoe and T. Welton, Chem. Commun., 2000, 2047.

4 While this manuscript was in preparation we learned that other groups have been working on asymmetric hydrogenation reactions in a $\mathrm{scCO}_{2} /$ IL biphasic system: P. G. Jessop, private communication; R. A. Brown, P. Pollett, E. McKoon, C. A. Eckert, C. L. Liotta and P. G. Jessop, J. Am. Chem. Soc., 2001, 123, 1254.

5 T. Welton, Chem. Rev., 1999, 99, 2071; P. Wasserscheid and W. Keim, Angew. Chem., Int. Ed., 2000, 39, 3772.

6 P. G. Jessop and W. Leitner, in Chemical Synthesis Using Supercritical Fluids, ed. P. G. Jessop and W. Leitner, Weinheim, Wiley-VCH, 1999; P. G. Jessop, T. Ikariya and R. Noyori, Chem. Rev., 1999, 99, 475.

7 D. K. Morita, D. R. Pesiri, S. A. David, W. H. Glaze and W. Tumas, Chem. Commun., 1998, 1397.

8 G. B. Jacobson, C. T. Lee, K. P. Johnston and W. Tumas, J. Am. Chem. Soc., 1999, 121, 11902.

9 Y. Chauvin, L. Mussmann and H. Olivier, Angew. Chem., Int. Ed., 1995, 34, 2698; B. Ellis, W. Keim and P. Wasserscheid, Chem. Commun., 1999, 337; C. J. Mathews, P. J. Smith and T. Welton, Chem. Commun., 2000, 1249.

10 P. G. Jessop, Y. Hsiao, T. Ikariya and R. Noyori, J. Am. Chem. Soc., 1994, 116, 8851; P. G. Jessop, Y. Hsiao, T. Ikariya and R. Noyori, J. Am. Chem. Soc., 1996, 118, 344

11 O. Kröcher, R. A. Köppel and A. Baiker, Chem. Commun., 1997, 453.

12 H. B. Wright and M. B. Moore, J. Am. Chem. Soc., 1948, 70, 3865; K. Takeshita and A. Kitamoto, J. Chem. Eng. Jpn., 1988, 221, 411.

13 L. A. Blanchard and J. F. Brennecke, Ind. Eng. Chem. Res., 2001, 40, 287.

14 L. A. Blanchard, Z. Gu and J. F. Brennecke, J. Phys. Chem., submitted.

15 D. E. Bergbreiter, Y. S. Liu and P. L. Osburn, J. Am. Chem. Soc., 1998, 120, 4250 